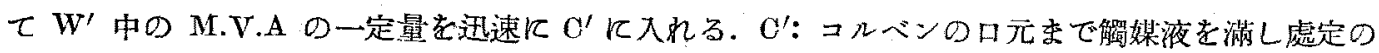
溫度に至つて $\mathrm{C}^{\prime \prime}$ 中に一部老流し一定量とする. 之と同時に $W^{\prime}$ 中の M.V.A. を $\mathrm{C}^{\prime}$-中に常厭に なる迄同しく一定量を探るＦ：ガスビュレットにして M.V.A. が触媒に吸收せられて $\mathrm{C}^{\prime}$ 中が減 壓になつて行く過程を水銀桂の差を以つて追涀する. $\mathrm{k}$ ：調節瓣. $\mathrm{a}, \mathrm{b}, \mathrm{c}, \mathrm{d}, \mathrm{e}, \mathrm{f}, \mathrm{g}:$ ガラスコック。 C' 中に一定容積即ちての實驗に於いては $680 \mathrm{ec} の$ M.V.A. を入れ水銀柱の差零の常暦上り测定を 開始する迄約 1 分間を要しその間の昅收狀况は不明である. 测定はストップオッチにて1分間置导 に記錄し $760 \mathrm{~mm}, 15^{\circ} \mathrm{C}$ の定常狀態に換算し，吸收せられた M.V.A.の比率を以つて吸收率(\%) とした.

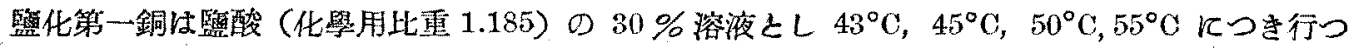
ז.

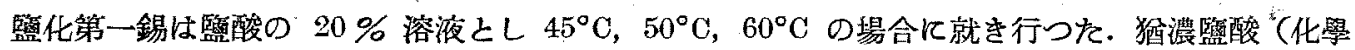
用）のみを $40^{\circ} \mathrm{C}$ にて用でた場合を行ひ比較した。

\title{
II. 測定結果並に考察
}

實驗結果は第 2 圖に示した如く、（1）. 監化第一錫の場合は監化第一銅に比し時間的に遏く吸收 能が現はれ又後者は $55^{\circ} \mathrm{C}$ ては吸收作用ないのに對し前者は $60^{\circ} \mathrm{C}$ にも吸收能を示した.（2） 测定に於いて低溫の方が吸收率大に現はれたが高い溫度の時は M. V.A. 及び監酸の蒸氣歷大とな

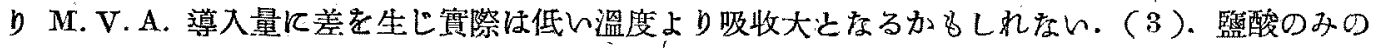
場合は吸收典線は直線となり一次反應型式に從ふが監化物存在の雨液の場合は波狀の曲線を示し斷 續的吸收が行ばれ觸媒效棵少明らかに示された。

終りに臨み御指導下された下里錠次氏並に發表を許可せられた石橋社長に感謝の意る表する。

$$
\text { （昭和二十一年十二月无日受領）（日本タイヤ株式會祛） }
$$

\section{東北地方の溫泉の地球化學的研究（第二, 三報）*}

The Geochemical Study on Mineral Springs in Tohoku Districts. II, III.

有井癸已雄永澤
Kimio ARII

（第二報）作並溫泉群につレて (II. On the Salkunami Spring Group.)

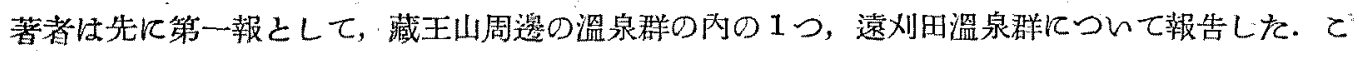
こには，作並溫泉群につんて昭和 18 年 4 月に行つた研究の結果を報告する.ての溫泉群は, 宮城

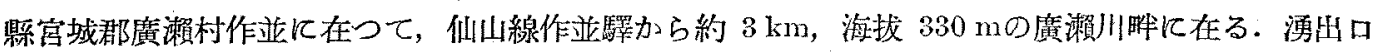
は全部で 9 個所する. その內譯は, 岩松旅館6 (第I, II 號泉, 瀧の湯, 應の湯, 新湯, 河原湯), 丸長旅館 1，作亚ホテル2 (神湯, ラヂウム泉)である.

各汿出口に於ける溫度, 泉水の $\mathrm{pH}, \mathrm{Cl}^{-}, \mathrm{SO}_{4}{ }^{-}, \mathrm{H}_{2} \mathrm{~S}, \mathrm{SiO}_{3}{ }^{2}, \mathrm{Rn}$ 等の含有量を定量したが，


ロが浴槽の中に在り，入浴客のをめに浴槽を干すかけに行かるかつたのて，涌出口をつきしめ得

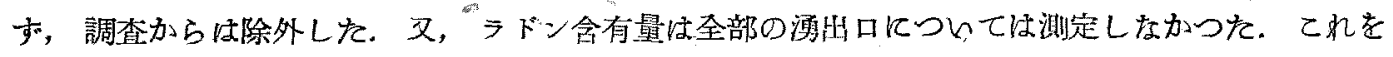


第 1 表

\begin{tabular}{|c|c|c|c|c|c|c|c|c|}
\hline 泉 & 名 & $\begin{array}{l}\text { 泉 }{ }^{\text {溫 }} \\
\left({ }^{\circ} \mathrm{O}\right)\end{array}$ & $\mathrm{pH}$ & $\begin{array}{l}\mathrm{Cl}- \\
\mathrm{mg} / \mathrm{l}\end{array}$ & $\begin{array}{l}\mathrm{SO}_{4}= \\
\mathrm{mg} / \mathrm{l}\end{array}$ & $\begin{array}{r}\mathrm{H}_{\mathrm{a}} \mathrm{S} \\
\mathrm{mg} / \mathrm{l}\end{array}$ & $\begin{array}{l}\mathrm{SiO}_{3}= \\
\mathrm{ng} / l\end{array}$ & $\begin{array}{c}\mathrm{Rn} \\
\times 10^{-10} \neq \pm-y-/ l\end{array}$ \\
\hline 庰松旅 & 领 I & 63.5 & 8.5 & 155.46 & 381.88 & 0.0675 & 185.71 & 5.12 \\
\hline 同 & II & $42.1<$ & 8.3 & 108.26 & 233.43 & 0.0378 & 132.20 & 26.64 \\
\hline$\infty$ & 湯 & 51.6 & 8.25 & 139.84 & 398.71 & 0.0269 & 98.26 & - \\
\hline$\infty$ & 湯 & 40.9 & 8.17 & $96.81^{\circ}$ & 131.72 & 0.0432 & 81.21 & - \\
\hline 新 & 湯 & 50.7 & 8.2 & 128.74 & 242.97 & 0.0829 & 86.67 & - \\
\hline 河原の湯 & No. 1 & 48.5 & 8.18 & 132.21 & - & - & - & - \\
\hline 同 & No..$^{5}$ & 52.4 & 8.22 & 131.17 & 263.28 & 0.0830 & 124.76 & - \\
\hline 同 & No. 3 & - & 8.10 & - & - & - & - & - \\
\hline 同 & No. 4 & 52.3 & 8.20 & - & - & - & - & - \\
\hline \multirow{2}{*}{\multicolumn{2}{|c|}{ 丸 長旅 館 の湯 }} & 58.3 & - & 158.23 & 336.41 & 0.0490 & 92.34 & 6.83 \\
\hline & & 47.2 & 6.90 & 117.27 & 263.28 & 0.0904 & 110.91 & 10.58 \\
\hline
\end{tabular}

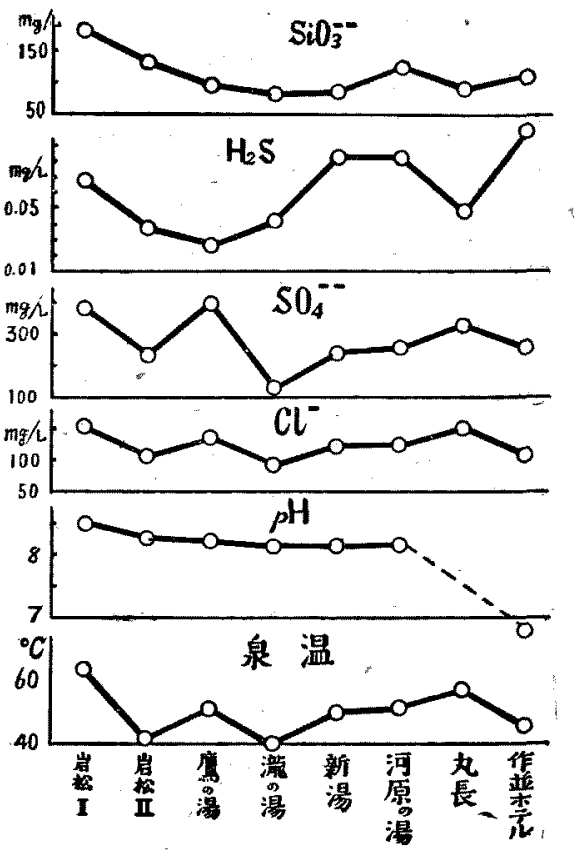

第 1 圆

圆示すると第 1 圆の如くになる。乙れを見ると，泉溫と $\mathrm{Cl}_{4}^{-}$及び $\mathrm{SO}_{\mathbf{4}}=$ の含有量が略々完全にその傾向を同じ くしてんることが知れる.それは.各涌出口の泉水は,同 一の組成をもつた溫泉が，溫度の低い循環水によつて稀 䆁されたものであるてとを示している. $\mathrm{H}_{2} \mathrm{~S}$ 及び $\mathrm{SiO}_{3}{ }^{2}$ の含有量が $\mathrm{Cl}^{-}$， $\mathrm{SO}_{4}-$-の含有量と傾向が逆になつてい るととは，てれ等が何れも主として，その循環水中に含 有されているものであららと侤えられる。尚、ラドン含 有量は特に大であるとは言い嗼いが，可成り多んことを たしかめた。

（第三報）中山平温家群につんて（III. On Nakayamadaira Spring Group.)

宫城縣玉造郡の鳴子町を中心こした一帶は，多数の温 泉が分布していて，古柬有名な溫泉地帶であるが，その 中の 1 群, 中山平泪泉群につんて昭和 18 年 8 月に行つ を調查絬果を報告する，乙の溫泉は鳴子町中山に在り， 大谷川棟に第 1 圖に示す如々分布している。惯出口は全

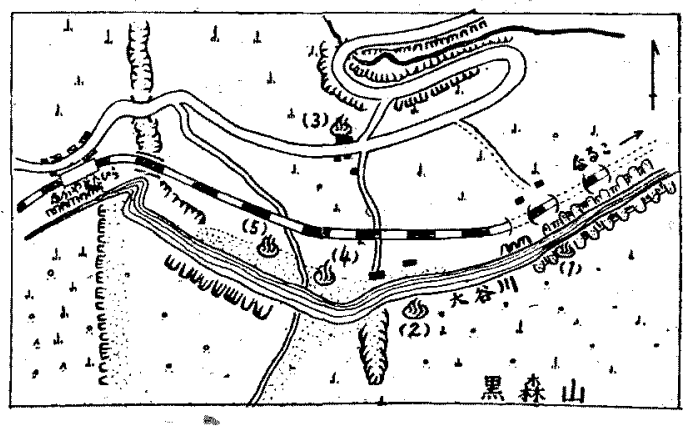

（1）吹上“泉 (2) 蛇湯 (3) 中山木テル

（4）仙生解, 星の湯 (5) 共同湯, 我鳥湯, 遊佐氏湯、

\section{，第 1 喕 中山溫泉略圆}

部で 8 個所である.

各涌活口に於ける溫度，泉水の $\mathrm{pH} ; \mathrm{Cl}^{-}$， $\mathrm{SO}_{4}=$ ，蒸發殘㵏， $\mathrm{Rn}$ 等を定量したが，蒸發殘， 滓を，泉水を持ち歸つて定量した外は，何れ8 現地で速に定量した。乙れ等の結果は第1表及 び第2圖に示してある。これを見ると，大體に於 て平行關係を保つて增減している。それは同一 の源泉（大谷川に沿的略束南加占北西之走る 方向にある，蛇湯，㳝庄館の湯を通る泉脈）の 
第 1 。表

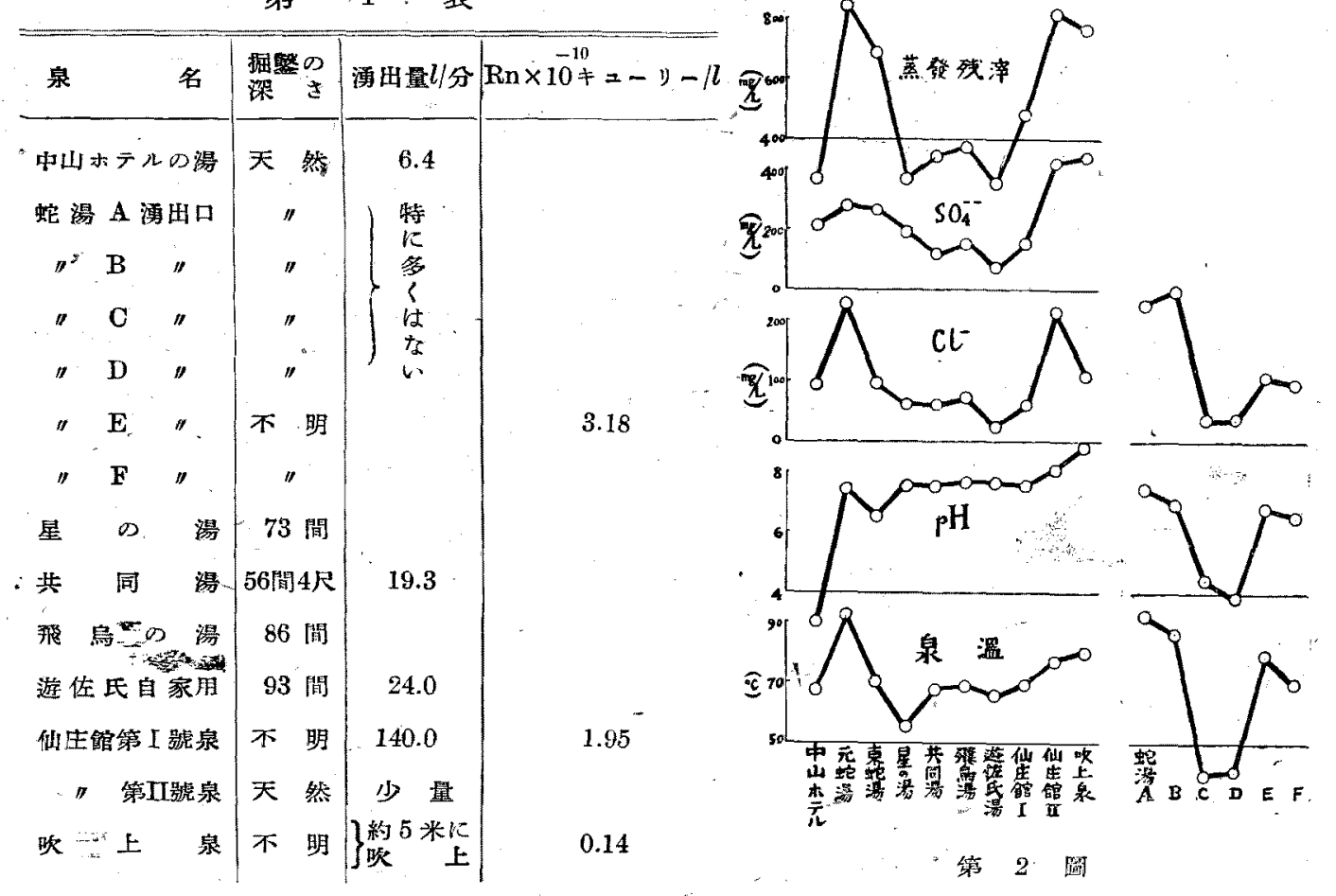


と見られる。然し，各溥出口によつて多少の特例がる。例えば，中山ホテルの湯は所謂硫黄泉で

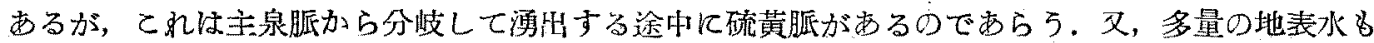
混大している. 東蛇湯（蛇湯 $\mathrm{F}$ 沩出口）の $\mathrm{pH}$ 及び $\mathrm{SO}_{4}=$ 含有量の傾向加多少他の溥出口のもの

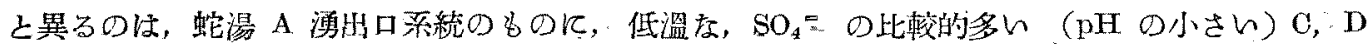

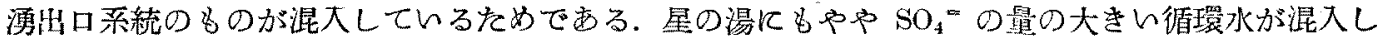

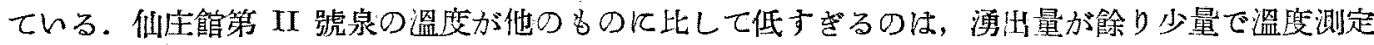
した場所え湧出する禁でに，水の混入によらすに，冷却してしまつているためでする，要するに中 山平溫泉群の地款深部から棑る源泉快同一のbので，それが大谷川に沿ら線に各所に溥出し，その 湧出の途中に混入して來る地表の循環水の量の多宾によつて, 泉溫, 成分含有量の多少等に差が出 來るものと洘えられる。

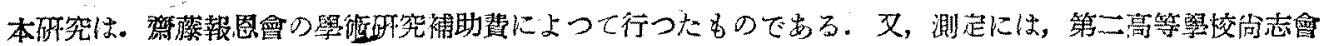

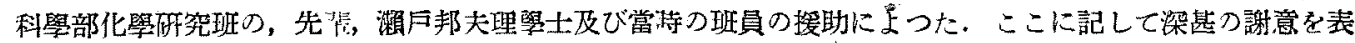
したい.

（昭和二十一被十二月二十三日受領）（第二高等學校） 